\title{
The Development of Sulfonamides (1932-1938) as a Focal Point in the History of Chemotherapy
}

\author{
By Marcel H. Bickel
}

The years around 1935 saw the discovery of Prontosil ${ }^{\mathrm{R}}$, the development of sulfanilamide and of a host of sulfonamide drugs as well as their widespread use in medicine. This sequence of events, which within only a few years contained everything from the idea to clinical routine treatment, resulted in a true revolution of chemotherapy, i. e., of the therapy of infectious diseases, and also contained the seeds for ideas and developments to come. Numerous accounts have been given of the dramatic events ${ }^{1-9}$; not all of them prove correct throughout if confronted with the original sources, and some of them may be biased because of their national origin in a highly competitive situation. Rather than correcting details of previous work, it is the aim of this study to give an account that emphasizes the manifold and lasting consequences of these discoveries around 1935 which may not have received adequate attention so far.

\section{Early History of Chemotherapy}

The chief prerequisite for the understanding of infectious diseases was the development of microbiology from about 1860 on. The first therapeutic application was immunotherapy as developed by Pasteur, Koch, Behring and Ehrlich between 1880 and 1900 . However, the limits of immunotherapy became obvious and caused Ehrlich to resume the path of chemotherapy he himself had initiated earlier in his life. Specific remedies against infectious diseases like mercury salts, quinine, and emetine had been used for centuries, yet they were still believed to strengthen the natural defense of the body rather than to act against the pathogenic microorganisms. On the other hand, the internal use of disinfectants was precluded because of their toxicity to the host as well as to the microorganisms ${ }^{10}$. Ehrlich's fascination with dyes and their selective affinity to different cell types motivated him to look for the dye that would not only accumulate in a pathogenic germ but would also damage or kill it. A first clinical trial along these lines was made with methylene blue in patients with malaria in 1881. The beginning of 
Ehrlich's "chemotherapeutic phase" was marked by his observation in 1904 that trypanosome-infected mice were cured by the azo dye, trypan red, which became the first synthetic chemotherapeutic agent. Rather than to continue along this line, Ehrlich then made use of two recent discoveries ${ }^{11}$ : the chemotherapeutic potential of organic arsenicals and the availability of an animal model of syphilis. The well-known result was arsphenamine (Salvarsan) in 1910, the first and overwhelming success of chemotherapy.

From Ehrlich on the search for chemotherapeutic agents followed the two tracks of dyes on the one hand and arsenicals and other heavy metal compounds on the other. Thus, a number of new and useful drugs $2,5,6,12,13$ were introduced into therapy during the period 1913-1932, among them the trypanocides acriflavine and suramine (Germanin), the first generation of antimalarials with pamaquine, primaquine, and mepacrine, the spirochetocidal oxphenarsine. All these drugs act against relatively differentiated microorganisms like protozoa and spirochetes but not against less organized bacteria which constitute the major pathogenic germs in non-tropical countries. Ehrlich's fear that bacteria may lack points of attack ${ }^{10}$ grew out into the general opinion in the 1920 s that bacterial infections are resistent to chemotherapy and may only yield to immunotherapy or stimulated phagocytosis ${ }^{6,12}$. Thus, despite efforts and occasional successes, chemotherapy around 1930 was regarded as a failure. Even Ehrlich's basic theories where being questioned, and the outlook on drugs against bacterial infections was rather gloomy ${ }^{14,15}$. Once more, a wave of therapeutic pessimism spread. It was by no means dissipated by Flemings's discovery in 1929 of an antibacterial principle named "penicillin", residing in nutrient broths of molds ${ }^{16}$. Fleming's inability to isolate the principle and use it as a chemotherapeutic drug was due not only to his lack of chemical techniques but also to the discouragement by his dominating boss, Almroth Wright, who simply did not believe in chemotherapy ${ }^{17-19}$.

\section{Domagk and the Discovery of Prontosil}

The German pathologist, Gerhard Domagk (1895-1964), assumed an academic career in Münster, Westphalia, where he specialized in the reticuloendothelial system and phagocytosis. In 1927 he joined IG Farbenindustrie in Wuppertal-Elberfeld as head of the bacteriology section where, around 1930 upon suggestion by his superior, Hörlein, he started a large- 
scale screening of agents for anti-streptococcal activity. Once more, this was carried out along the lines of heavy-metal compounds and dyes. Unlike many efforts to achieve the goal of chemotherapy of bacterial diseases since Ehrlich, Domagk's crucial experiment of December 1932 marked the breakthrough. His results, published in February $1935^{20}$, can be summarized as follows:

1) A strain of Streptococcus haemolyticus originating from a lethal case of human sepsis was used as a new disease model in mice. All infected animals died within 1-2 days and showed streptococci in blood and tissues.

2) Some gold compounds as well as acridine and azo dyes showed chemotherapeutic activity in vitro, but were toxic or inactive in vivo.

3) The azo dye, Prontosil, even though inactive in vitro, had the most pronounced chemotherapeutic effect ever observed in vivo. All infected animals survived without symptoms. Streptococci had disappeared, and leukocytes showed signs of increased phagocytosis.

4) The toxicity of Prontosil was very low; $1000 \mathrm{mg} / \mathrm{kg}$ being tolerated without untoward effects.

Prontosil, synthesized by Mietzsch and Klarer at IG Farbenindustrie, is a relatively simple azo dye, containing a sulfonamido group attached to the classic dye, chrysoidine (see formula):

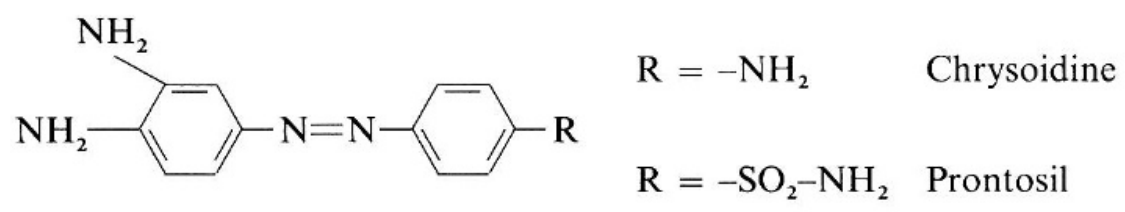

As a historical curiosity in retrospect it can be mentioned that Hörlein had worked with sulfonamido azo dyes in 1909 and that both chrysoidine and sulfamido azo dyes had been ascribed a weak antibacterial activity ${ }^{4}$. However, these findings were based on inadequate test methods. To our knowledge, the lag of over two years between Domagk's observation and its publication has not been convincingly explained. One obvious effect of the late date of publication was its being accompanied by the first clinical reports, all favorable, which appeared simultaneously ${ }^{21-23}$ as a result of clinical testing during the two years. This made Domagk's discovery immediately credible and convincing which, in the climate of chemotherapeutic disbelief, may have been decisive. The most famous patient treated 
with Prontosil was Domagk's own daughter who may have been saved from the threatening consequences of septicemia by her father's injections of the new drug ${ }^{24}$. Clinical use of Prontosil soon spread from Germany across the borders.

Domagk's experimental observations did not go unchallenged. Only months after his classic paper ${ }^{20}$ the French groups of Levaditi and Vaisman ${ }^{25}$ and of Nitti and Bovet ${ }^{26}$ confirmed the action of Prontosil on mice infected with streptococci, but at the same time emphasized that the drug was inactive against strains of low virulence and that the results with highly virulent strains were variable, in contrast to the report of Domagk. In the following year Colebrook and Kenny ${ }^{27}$ pointed out that Domagk did not report the fate of his surviving animals beyond the 7 th day and that the clinical papers made little allowance for spontaneous recovery and provided scanty clinical and bacteriological data. Still, the clinical success of Prontosil and the further development made Domagk's discovery a turning point and the beginning of a breath-taking series of events that should revolutionize the therapy of infectious diseases. For his contributions he was awarded the Nobel prize in 1939 but was refused its acceptance by the Nazis. The honor was restored in Stockholm after the war, but, according to the rules, the money had been returned to the fund.

\section{The Decisive Contribution of the Institut Pasteur}

The second act happened at the prestigious Institut Pasteur in Paris. The medicinal chemist, Ernest Fourneau (1872-1949), head of the Laboratoire de Chimie Thérapeutique, had a long career of successful contributions to chemotherapy and other fields of pharmacotherapy ${ }^{2,28}$. In particular, he had a keen instinct in unravelling unpublished secrets of the successful German drug industry. As has been mentioned above, Domagk made his discovery of Prontosil in 1932 but published it only in February 1935. However, from 1933 on some clinical papers appeared in Germany without mentioning Prontosil or its formula specifically, which might have been a sign that something new was brewing ${ }^{1}$. A patent on Prontosil was published in 1934. This, and of course Domagk's classic publication, were known to the Fourneau group ${ }^{29}$.

The latter publication immediately initiated studies on the structureactivity relationships of Prontosil, based on the conviction that they exist 
for antibacterial as for antiprotozoic activity ${ }^{4}$. A first short communication by Nitti and Bovet ${ }^{26}$, who were able to partially confirm the antistreptococcal activity in vivo of Prontosil, appeared in July 1935. Federigo Nitti was a microbiologist who at the beginning of his career had just joined the Fourneau team, while Daniel Bovet at that time was already an experienced pharmacologist.

In the same year 1935, only nine months after the appearance of Domagk's classical paper, the key work of the Institut Pasteur group appeared under the title (translated): "Activity of Sulfanilamide on Experimental Streptococcal Infections of Mice and Rabbits" ${ }^{30}$. It came in the modest form of a two page abstract of the November 23 session of the Sociéte de Biologie. The authors were the chemists, J. Tréfouël and his wife, F. Nitti, and D. Bovet. Much as this work was based on Domagk's discovery, it was much more than just another discovery. In fact, it contained the key to the development of bacterial chemotherapy and thus belongs to the great texts of modern medicine. Its clear style and extreme density of invaluable information makes it a masterpiece in form as well as in content. The results can be summarized as follows:

1) The introductory paragraph (Fig. 1) gives full credit to Domagk and immediately reveals an extensive screening for antistreptococcal activity in vivo within selected azo dyes of the general Prontosil-like formula

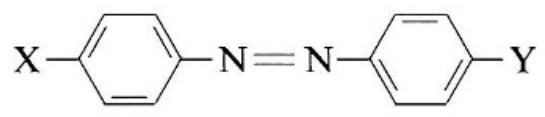

(where X stands for alkyl-, amino-, or phenolic groups).

2) The following relationships with respect to $\mathrm{Y}$ emerged:

$$
\begin{array}{rlr}
\mathrm{Y} & =-\mathrm{SO}_{2}-\mathrm{NH}_{2} & \text { active } \\
& =-\mathrm{O}-\mathrm{CH}_{2}-\mathrm{CH}_{3} & \text { inactive } \\
& =-\mathrm{CN} & \text { inactive } \\
& =-\mathrm{CH}_{2}-\mathrm{CN} & \text { inactive } \\
& =-\mathrm{CO}-\mathrm{NH}_{2} & \text { inactive }
\end{array}
$$

3) Since all dyes containing a sulfonamido group on one of the benzene rings were active regardless of the substituents of the other ring, the authors assume that the compounds in the body undergo a splitting of the azo bond according to the scheme 
Fig. 1 Heading, first, and last paragraph of the classical report of Tréfouël, Tréfouël, Nitti and Bovet, $1935^{30}$

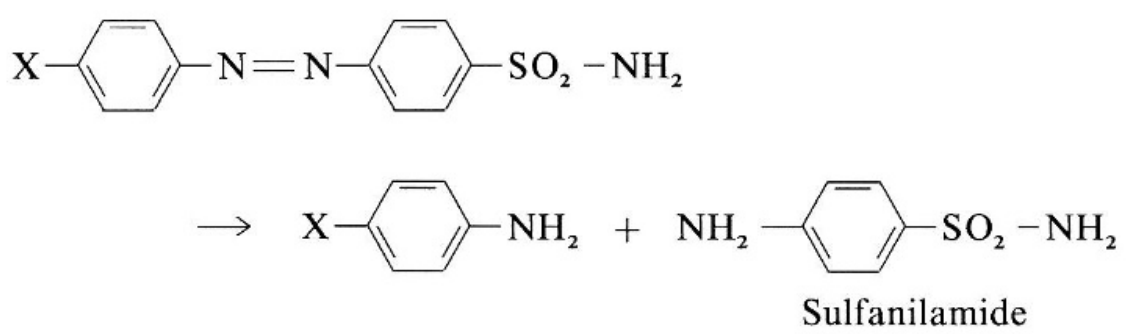

4) Indeed, sulfanilamide as the common cleavage product of the above sulfonamide compounds has a pronounced chemotherapeutic effect on streptococcal infections, comparable to Prontosil. Again, blood cultures are negative.

5) The toxicity of sulfanilamide is very low; $1000 \mathrm{mg} / \mathrm{kg}$ being tolerated without untoward effects.

6) Derivatives of sulfanilamide, if substituted in the sulfonamido nitrogen, are also active.

7) The final paragraph (Fig. 1) states that the activity of sulfanilamide as a simple molecule which is not a dye will allow a systematic chemotherapeutic study, comparable to the one that led to arsphenamine (Salvarsan).

The far-reaching consequences of this historical document will be discussed below. Another report by the same team ${ }^{31}$, published in 1936, gives more detailed information on the structure-activity relationships of 130 tested compounds, among them 46 sulfanilamide derivatives. The conclusions can be condensed into the following general formula of active sulfonamides

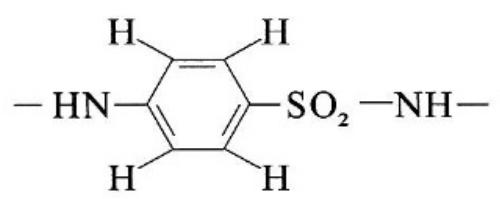

A first full paper on the subjet appeared only in $1937^{32}$. 
ACTivité dU P-AMINOPHÉNYLSULFAMIDE

SUR LES INFECTIONS STREPTOCOCGIQUES EXIÉRIMENTALES

DE LA SOURIS ET DU LAPIN,

par J. et Mme J. Théfouël, F. Nittr et D. Bovet.

Les récents travaux de Domagk, dans le domaine des sulfamidochrysoïdines, qui ont abouti aux Prontosils, travaux confirmés par Levaditi et Vaisman, Nitti et Bovet ( $\mathrm{I}^{*}$ ), ont remis à l'ordredu jour la chimiothérapie des infections bactériennes. Ayant préparé et expérimenté divers produits résultant de la copulation du diazoïque de l'aminosulfamide avec des mono-et des poly-phénols alcoylés ou non, nous nous sommes rendu compte que des dérivés assez diflérents du Prontosil au point de vue de leurs propriétés physiques et chimiques présentaient un pouvoir antistreptococcique analogue.

L'activilé thérapeutique d'une molécule aussi simple, qui n'est pas elle-mème une matière colorante, ouvre la voie à une étude systématicfue de chimiothérapie comparable à celle qui a été pouranivie dans le domaine de l'arsenic pentaralent.

(Laboratoire de chimie thérapentique de M. E. Fourneau.

Laboratoire des vaccins de M. A. Salimbeni, Institut Pasteur.)

\section{From Prontosil to Sulfanilamide to Sulfonamides}

The classical contribution of the Institut Pasteur group gave no proof whether Prontosil is really metabolized to sulfanilamide. According to Bovet ${ }^{29}$ the primary aim of the team was to prove the chemotherapeutic activity of sulfanilamide in vivo, and the long-term interest was in its mechanism of action rather than in drug metabolism. Hence, only after having demonstrated the activity of sulfanilamide did they propose the hypothesis of its metabolic formation from Prontosil. This was based on a 
study of $1911^{33}$, according to which a number of azo dyes undergo reductive cleavage of the azo bond in the dog. However, the proof of the hypothesis was soon to follow. In 1936 Colebrook et al. ${ }^{34}$ in London demonstrated that, in contrast to Prontosil, sulfanilamide was active in vitro and that the former could be converted to the latter by chemical reduction with magnesium. They also found ${ }^{27,34}$ that the serum of patients or animals treated with either Prontosil or sulfanilamide was active against streptococci in vitro. In the same year Kellner ${ }^{35}$ reported that rabbits excreted less than a fourth of a dose of Prontosil unchanged in the urine and suggested that the reminder was reduced and excreted as sulfanilamide or a derivative of it. The final proof was provided in the following year 1937 by Fuller ${ }^{36}$ in Colebrook's team. He analyzed the urines of patients and mice treated with Prontosil and found that some $50 \%$ of the drug had indeed appeared as sulfanilamide in conjugated form. This left no doubt that sulfanilamide was the active metabolite of Prontosil.

It is of interest that Domagk in $1936^{24}$ quoted the Institut Pasteur work without being challenged by its results, while in $1937^{37}$ he explicitly dismissed the metabolic reduction of Prontosil. Only in 1940 did Domagk concede that active chemotherapeutics may be formed by metabolic conversion ${ }^{38}$.

Early personal contacts of Colebrook and his collaborators with Hörlein from IG Farben and Bovet from the Institut Pasteur may have contributed to a rapid and enthusiastic acceptance of the new possibilities in the field of chemotherapy by the British. In a series of papers ${ }^{27,39-41}$ the Colebrook group as early as 1936 and 1937 gave evidence of their successful use of Prontosil, and soon of sulfanilamide, in puerperal infections due to hemolytic streptococci, as well as in the deadly acute meningitis. Sulfanilamide was even recommended for prophylactic use for births in problem environments.

Surprisingly, no publication on Prontosil or sulfanilamide appeared in the American medical literature until 1937. It was the time when great discoveries published in German and French still could go unnoticed in the United States. As a result, this country lagged well behind Europe. Only under the influence of Colebrook's papers did the U.S. feel the full impact of the new development. Highly important clinical and experimental contributions were soon to be made by Long and Bliss ${ }^{1}$ and by Marshall, both at Johns Hopkins University. Marshall's leading studies on analytical methods ${ }^{42,43}$, absorption ${ }^{43}$, distribution ${ }^{43,44}$, excretion ${ }^{43,45}$, metabolism ${ }^{46}$, and toxicity ${ }^{47}$ of sulfanilamide set an example on how to gather comprehen- 
sive knowledge on the fate of a drug in the body. Among his major contributions were the findings that sulfanilamide in the body undergoes conjugation with acetic acid and that this acetylated metabolite is somewhat more toxic than the parent compound.

Clinical use of sulfanilamide became wide-spread from 1936 on. The early reports on its low toxicity were confirmed even though adverse effects ${ }^{27,43,47,48}$ such as acidosis and temporary decrease of kidney function were described in the early years. A drug disaster that cost the lives of at least 76 patients happened in the fall of 1937 in connection with, but not causally related to sulfanilamide ${ }^{49}$. In order to improve oral administration of the poorly water-soluble sulfanilamide, the Massengill company in the U.S. introduced a new formulation of $10 \%$ sulfanilamide dissolved in $76 \%$ diethylene glycol under the name of Elixir of Sulfanilamide. An immediate forensic and experimental study ${ }^{49}$ left no doubt that the victims had died from uremia as a consequence of the nephrotoxicity of diethylene glycol which leads to intracellular edema, tubular obstruction and anuria. The immediate action prevented a still larger catastrophe. The authors of the full report ${ }^{49}$ pointed out that no animal tests had been performed by the manufacturer, and they emphasized that too many drugs were introduced without adequate study and that tragedies can only be avoided by enforced toxicity studies.

All the events and developments discussed so far took place within a few years around 1935. Their consequences, most of them stemming from the two classic publications of $1935^{20,30}$, reached far beyond and down to our time. The most important was the development of the sulfonamides, a whole class of chemotherapeutic drugs, based on the structure-activity relationships indicated by the Institut Pasteur group ${ }^{30-32}$. The first of these sulfanilamide derivatives with a substituent attached to the sulfonamide nitrogen was sulfapyridine. The new drug, developed in Britain in 1937, was a striking success. Many more sulfonamides were to follow from 1938 on, both in Europe and the United States. Their superiority compared to sulfanilamide was obvious. They were better absorbed and tolerated, they had an increased and prolonged effectiveness, and their spectrum of action became broader. Thus, many infectious diseases became amenable to therapy, among them pneumonia, meningitis, gonorrhea, brucelloses, peritonitis, pyelonephritis, some infective bowel and urinary tract diseases, and many more, in addition to the ones that had already been successfully treated with Prontosil and sulfanilamide. The number of patents was $1300 \mathrm{in}$ 
1940 and increased to 6500 in 1951. In 1943 in the U.S. alone 4500 tons of sulfonamides were produced and millions of patients treated ${ }^{18}$. Some 1000 sulfonamides appeared on the market; most of them were short-lived, but a limited number of strongholds stood the test of time. Even though heavily superseded by antibiotics during the last decades, sulfonamides still have their place in modern therapy as for cystitis, burns, and ulcerative colitis, and finally, in combination with dihydrofolate reductase inhibitors they have become among the most potent weapons against a host of infectious diseases ${ }^{7}$. Furthermore, sulfonamides were also a starting point for the development of new and important classes of drugs such as diuretic, uricosuric, hypoglcemic, antithyroid, and anti-leprosy agents ${ }^{50}$.

The striking discoveries of the antibacterial activities of Prontosil and sulfanilamide immediately led to speculations and investigations on their mechanism of action. Domagk in his initial report ${ }^{20}$ dismissed a nonspecific action such as activation of phagocytosis on the grounds that Prontosil acted "specifically" on streptococci and staphylococci. The Institut Pasteur group working with the active metabolite, sulfanilamide, observed a direct action on molds which the authors described as an inhibition of development rather than an antiseptic action ${ }^{51}$. Colebrook et al. ${ }^{27,34}$ similarly observed that the growth of streptococci was retarded rather than suppressed and that the germs underwent slow destruction after a period of active multiplication. An American team confirmed that the activity was due to bacteriostatic rather than bactericidal properties ${ }^{52}$. The mechanism of action was eventually elucidated and published by Woods and Fildes in 1940 52, 54. Based on the observation of a factor in streptococci which antagonized sulfonamides, a keen hypothesis was postulated and proved correct. Sulfonamides are structural analogs of the streptococcal factor, para-aminobenzoic acid, a precursor of folic acid and hence an essential metabolite of many bacteria. By their very structural similarity, sulfonamides act as "antimetabolites" which prevent the use of the essential metabolite by its enzyme, thereby inhibiting a vital process. Thus, the bacteriostatic action of sulfonamides is due to interference with an essential metabolite of bacteria.

\section{The Major Consequences for Chemotherapy and Beyond}

In this final chapter the major consequences of the initiation of chemotherapy with sulfonamides will be summarized under eight aspects. Most of 
them originate in the one year 1935 which saw the discoveries of Prontosil and sulfanilamide and is therefore a focal point in the history of chemotherapy. Even more surprising, most of these consequences emerged from the one paper by Tréfouël, Tréfouël, Nitti, and Bovet ${ }^{30}$, in which the last author must have played the leading part. This paper rightfully has become a classic text of modern history of medicine. Only two aspects discussed in this chapter originate in the years 1937 and 1940, respectively.

1) As has been mentioned in chapter I, Ehrlich's earlier chemotherapeutic work led to the notion that dyes may provide a reservoir of potential chemotherapeutic drugs. After a long period of few successes and many failures, Domagk's large-scale screening that resulted in the discovery of Prontosil ${ }^{20}$ in 1935 marked the culmination of Ehrlich's dye theory. However, the demonstration by the Institut Pasteur group ${ }^{30}$ later in the same year that the antibacterial activity was due to sulfanilamide which is an active metabolite of Prontosil and no longer a dye, made the dye theory vanish almost over night. Thus, 1935 marked both the zenith and the death of this theory. The door to the search of new and better anti-infective drugs was pushed wide open, and the successes were as immediate as they were impressive. It is easy in retrospect to criticize Ehrlich's dye theory as naive or even as "an idée fixe of German Science" 7. After all, it was a useful crutch, and it became a great example of a wrong hypothesis eventually leading to the truth.

2) It has also been mentioned in chapter I that anti-infective drugs were believed to strengthen the natural defense of the host rather than kill the pathogenic germs as disinfectants do. This notion did not fade in the advent of active chemotherapeutic research but, on the contrary, was supported by some experimental evidence. Thus, while Ehrlich was convinced that chemotherapeutic agents cure diseases by virtue of their germicidal action, Uhlenhut, who was equally engaged in chemotherapeutic research, emphasized the former theory. His judgement was based on his successful treatment in 1907 of a chicken spirillosis with the early organic arsenical, atoxyl, which was not active in vitro ${ }^{55}$. Uhlenhut noted that the spirochetes retained their motility and virulence in a solution of atoxyl and concluded that the drug would reinforce body cells and leukocytes in their fighting-off germs. The same problem was faced by Domagk as late as 1935 when Prontosil proved to be active in vivo but inactive in vitro. In his own comment ${ }^{20}$ he apparently leaned toward Uhlenhut's theory in emphasizing 
that Prontosil acts like a true chemotherapeutic agent in being active in vivo only. On the other hand, he dismissed an indirect action like activation of phagocytosis because of the apparently restricted effect on streptococci and staphylococci. In fact, Prontosil would have been a last case for the old theory. The demonstration of the in vitro activity of sulfanilamide as the active moiety changed it all and was the final victory of Ehrlich's theory that chemotherapeutic drugs act against pathogenic microorganisms.

The fact that the in vitro activity of sulfanilamide was not reported by the Institut Pasteur group but was proved later by Colebrook's team ${ }^{34}$ is an interesting detail. As it turned out later, the former authors dit not succeed because of their use of culture media rich in the "anti-sulfonamide factor", para aminobenzoic acid (PABA), whereas the latter were luckier with serum as a medium poor in $\mathrm{PABA}{ }^{29}$.

3) Prontosil was the result of a large-scale screening by IG Farben, followed by a careful clinical evaluation. After the immediate clinical success the outlook for the company, in terms of both prestige and profit, could not possibly be brighter. After all, IG Farben would for many years be the sole manufacturer of this miracle-drug which was covered by patents. This euphoria was shattered in its beginning when the French came up with sulfanilamide. Not only was this the active principle and therapeutically equal if not superior to Prontosil, but worst of all for the Germans, sulfanilamide was not eligible for a patent. The compound was so simple that it had been synthesized and described way back in $1908^{56}$. It had been one of the many synthetic chemicals of no use, gathering dust on some shelf. Thus, without being protected by a patent, sulfanilamide went directly into competitive production. By 1937 more than 100 manufacturers were busy producing the drug. Therefore, even though protected by a patent, Prontosil did not become a bestseller, and for lack of a patent and being easy to make, sulfanilamide, the first and long-awaited antibacterial, became a cheap and easily available drug from the beginning.

4) The early work of the Institut Pasteur group ${ }^{30}$ not only contains the step from Prontosil to sulfanilamide, but also from there to sulfonamides in that it elaborated the structure-activity relationships of over 100 sulfanilamide derivatives, clearly demonstrating that those derivatives with a substituent at the nitrogen of the sulfonamido group may also be active. Thus, sulfanilamide became a classical lead compound for the screening of other chemotherapeutic drugs. Success came quickly, and from 1937 on the development was like a gold rush, since in contrast to sulfanilamide each of 
its derivatives was patentable so that each drug company would market "its" sulfonamide(s). To be sure, the quantitative developments in terms of number of sulfonamides had more than just commercial significance in that it gave the new anti-infective therapy a broad base and general acceptance. In scientific terms, it became clear by 1940 that all sulfonamides have the same mechanisme of action ${ }^{53,54}$, which in turn increasingly focused attention to the pharmacokinetic differences and how these would influence pharmacodynamics and medical indication of the individual products.

5) From the 1940 's on penicillin and other antibiotics were introduced as new generations of anti-infective drugs, which by their success clearly overshadowed and outran sulfonamides. As has been mentioned in chapter I, chemotherapy from about 1920 on had been regarded as a failure, and as a result a new wave of therapeutic pessimism spread. It was in this climate that Fleming in 1929 discovered "penicillin" as an antibacterial principle residing in nutrient broths of a mold culture ${ }^{16}$. Typically, he injected "penicillin", i.e., a very diluted solution of penicillin, into mice in order to test for toxicity, but he did not inject it into infected mice as a test for chemotherapeutic action. When Florey and Chain in 1939 reinvestigated Flemings's lysozyme and penicillin, it was initially for general biological rather than chemotherapeutic interest ${ }^{17}$. However, sulfonamide therapy at that time was in full swing and had changed the attitude thoroughly by giving chemotherapy full credibility. Once a relatively simple way to attack pathogenic microorganisms without damaging the host had been found, why should not other ways be successful? Thus, there can be not doubt that Florey and Chain soon included the chemotherapeutic aspect which eventually became the overwhelming motivating power for the isolation and mass production of penicillin in Britain and the United States ${ }^{6,18}$. The earlier development of Prontosil, sulfanilamide, and sulfonamides was therefore a pacemaker for antibiotics as the second wave of attack against infectious diseases.

6) Among the consequences to be discussed some are of major scientific rather than chemotherapeutic importance. The metabolic conversion of Prontosil into sulfanilamide, postulated by the Institut Pasteur group ${ }^{30}$ and proved by Fuller ${ }^{36}$, was much more than just another example ${ }^{33}$ of a reductive cleavage of an azo dye. The paramount significance of this biotransformation was that the inactive compound, Prontosil, was metabolized to form the active metabolite, sulfanilamide. This aspect has been recently reviewed ${ }^{57}$. In 1935 the studies on the metabolism of foreign 
compounds had a history of almost a century. They suggested that drugs and toxic chemicals underwent biotransformation to form less toxic metabolites. The term, "detoxication", met with so much success that "detoxication mechanisms" for over half a century became synonymous with what today is called drug metabolism. The discovery that the metabolism of Prontosil to sulfanilamide was a bioactivation rather than a detoxication, marked the end of the deeply-rooted theory of detoxication. However, recognition that drug metabolism was no longer identical with detoxication came about slowly in the late 1940 's and became generally recognized only in the 1960 's. Still later, bioactivation became a backbone of modern toxicology. Surprisingly, the aspect of bioactivation was not discussed by its discoverers in the 1930 's. The Institut Pasteur group was aware ${ }^{29}$ of the azo bond being easily cleaved in the body ${ }^{33}$, as it was aware of the metabolic reduction of indifferent pentavalent arsenic into the toxic trivalent species, one of Ehrlich's findings ${ }^{11}$ which had been confirmed by Fourneau's work at the Institut Pasteur. To be sure, arsenic being an element has to be considered a special case, and recently the metabolic oxidation, i.e., detoxication, of the trivalent species has also been shown ${ }^{58}$. The fact remains that the biotransformation of Prontosil to sulfanilamide was the first example of bioactivation within the realm of organic compounds.

Interestingly, a second example followed immediately when Marshall et al. ${ }^{47}$ showed that sulfanilamide was metabolized to the more toxic acetylated derivative. Thus, not only was sulfanilamide an active metabolite of an inert precursor itself, but it would in turn lead to the formation of more toxic metabolites. Finally, sulfanilamide became the model substrate used to unravel the mechanism of metabolic acetylation ${ }^{59,60}$, one of the key processes in biochemistry.

7) Whereas chemotherapy for Ehrlich was only conceivable as a bactericidal action or "internal sterilization", it was only with the investigation of sulfanilamide and other sulfonamides that the concept of growth inhibition or bacteriostasis was shaped. This concept, however, was only a first step before the great discovery of the specific mechanism of action of sulfonamides by Woods and Fildes ${ }^{53,54}$ who demonstrated the molecular mechanism of these drugs as antagonists of the bacterial metabolite, para-aminobenzoic acid. They thereby introduced the concept of antimetabolites and competitive inhibition of enzymes which would be extended to receptors in our time. Their discovery clearly demonstrated that structural analogs of a substrate or drug could not only be active like the parent compound or else inactive, 
but that by retaining affinity and lacking efficacy they could act as competitive inhibitors of the enzyme or receptor in question. This was indeed a concept of paramount importance for biochemistry and pharmacology. Practical consequences for the latter field soon became visible with the advent of improved screening methods for new drugs, particularly receptor antagonists like antihistaminics or beta-blockers.

8) A final important consequence in connection with the introduction of sulfonamides concerns drug regulation and legislation. The increase in the number and efficacy of drugs at the end of the last century resulted in a first step of drug regulation in the U.S. in 1906 with the Federal Pure Food and Drug Act. This act was only concerned with purity and attached no strings on sale nor obligations to prove the safety and efficacy of a drug to be marketed. This was not felt a disadvantage during the first decades of our century, a time of therapeutic pessimism with few new drugs introduced. However, this situation was to change with the advent of sulfonamide therapy. The disaster in 1937 with the Elixir of Sulfanilamide and its heavy death toll came as a shock. No submission to the Food and Drug Administration (FDA) had been made for this formulation, which was not illegal at the time. An immediate investigation identified the cause of the mass intoxication to be diethylene glycol, the solvent used for sulfanilamide ${ }^{49}$. The authors of the report, Geiling and Cannon, pointed out that little data on the toxicity of diethylene glycol were at hand, but that the symptoms in patients were identical to the ones produced in animals and therefore could have been predicted. They also made a number of recommendations in order to avoid similar tragedies, among them compulsory toxicity studies on animals for new products. In addition, they issued a warning to physicians, not to prescribe unofficial drugs, since too many of them had not been adequately studied. Clearly, this immediate intervention of the American Medical Association and the FDA prevented a still larger disaster with Elixir of Sulfanilamide. More than this, the event had a far-reaching result. Within months the Congress enacted the Food and Drug Act, an amendment of the 1906 legislation, in order to protect users from unsafe drugs. This 1938 act was concerned with labeling and safety through toxicity studies. It requested an approval of a new drug application before a drug could be marketed, and the enforcement of the act was entrusted to the FDA. Thus, the dark event of 1937 was turned into a milestone in the history of drug regulation. Still more stringent obligations in drug regulation were introduced from the 1960 's on. 


\section{References}

1 P.H.Long, E. A. Bliss: The clinical and experimental use of sulfanilamide, sulfapyridine and allied compounds. The Macmillan Comp. New York (1939).

2 J.Tréfouël, J.Tréfouël, D.Bovet, F. Nitti: The contribution of the Institut Pasteur, Paris, to recent advances in microbial and functional chemotherapy. Brit. Med.Bull. 4 (1946) 284-289.

3 G.Bickel: Die Sulfonamide in der modernen Chemotherapie. Chemotherapie (Wissenschaftlicher Dienst [Roche]), Roche Basel (1964) 24-32.

4 J.Tréfouël: Historique de la découverte des sulfamides. Méd. Hygiène 23 (1965) 150-151.

5 B. Issekutz sen.: Die Geschichte der Arzneimittelforschung. Akadémiai Kiadó Budapest (1971).

6 H.Schadewaldt: Die Entdeckung der Sulfonamide. D.med.Wschr. 100 (1975) 2617-2621.

7 Editorial: Fifty years of sulphonamides. Lancet (1985I) 378.

8 H.Schadewaldt: 50 Jahre Sulfonamide. D.med. Wschr. 110 (1985) 1179-1181.

9 W.Schreiber: Vor 50 Jahren: Entdeckung der Chemotherapie mit Sulfonamiden. D. med. Wschr. 110 (1985) 1138-1142.

10 H. Bechhold, P. Ehrlich: Beziehungen zwischen chemischer Konstitution und Desinfektionswirkung. Z.physiol. Chemie 47 (1906) 173-199.

11 P.Ehrlich: Über den jetzigen Stand der Chemotherapie. Ber.deut.chem.Ges. 42 (1909) 17-47.

12 G.Domagk: Chemotherapie der bakteriellen Infektionen. Angew. Chemie 42 (1935) 657-676.

13 P. Klein: Zur Ideengeschichte der chemotherapeutischen Frühperiode. D. med.Wschr. 91 (1966) 2281-2284.

14 I. Galdston: Some notes on the early history of chemotherapy. Bull. Hist. Med. 8 (1940) 806-818.

15 J.Parascandola: The theoretical basis of Paul Ehrlich's chemotherapy. J.Hist. Med. Allied Sci. 36 (1981) 19-43.

16 A. Fleming: On the antibacterial action of cultures of a penicillium with special reference to their use in the isolation of B.influenzae. Brit. J.exp. Pathol. 10 (1929) 226-236.

17 E. Chain: A short history of the penicillin discovery from Fleming's early observations in 1929 to the present time. In: J.Parascandola (ed.), "The History of Antibiotics. A Symposium." Am. Inst. Hist. Pharm. Madison, WI (1980) 15-29.

18 G. L. Hobby: Penicillin. Meeting the challenge. Yale University Press, New Haven/London (1985).

19 J. Howie: Penicillin: 1929-1940. Brit. Med.J. 293 (1986) 158-159.

20 G. Domagk: Ein Beitrag zur Chemotherapie der bakteriellen Infektionen. D. med.Wschr. 61 (1935) 250-253.

21 P. Klee, H. Römer: Prontosil bei Streptokokkenerkrankungen. D. med.Wschr. 61 (1935) 253-255.

22 H.T.Schreus: Chemotherapie des Erysipels und anderer Infektionen mit Prontosil. D. med.Wschr. 61 (1935) 255-256. 
23 E.Anselm: Unsere Erfahrungen mit Prontosil bei Puerperalfieber. D.med.Wschr. 61 (1935) 264-265.

24 G.Domagk: Chemotherapie der Streptokokkeninfektionen. Klin.Wschr. 15 (1936) $1585-1590$.

25 C. Levaditi, A.Vaisman: Action curative du chlorhydrate de 4-sulfamido-2,4-diaminoazobenzène et de quelques dérivés similaires, dans la streptococcie expérimentale. C.R.Soc.Biol. (Paris) 119 (1935) 946-949.

26 F. Nitti, D. Bovet: Action du 4-sulfonamide-2-4-diaminobenzol (prontosil) sur des infections streptococciques de la souris provoquées par des streptocoques d'origine humaine. C.R.Soc.Biol. (Paris) 119 (1935) 1277-1280.

27 L. Colebrook, M. Kenny: Treatment of human puerperal infections, and of experimental infections in mice, with prontosil. Lancet (1936I) 1279-1286.

28 D. Bovet: Hommage à Ernest Fourneau. L'œuvre d'Ernest Fourneau et les développements de la chimie thérapeutique contemporaire. Chim.thérap. 7 (1972) 417-424.

29 D. Bovet: Personal communications.

30 J.Tréfouël, J.Tréfouël, F. Nitti, D. Bovet: Activité du p-aminophénylsulfamide sur les infections streptococciques experimentales de la souris et du lapin. C.R.Soc.Biol. (Paris) 120 (1935) 756-758.

31 E. Fourneau, J.Tréfouël, J.Tréfouël, F. Nitti, D. Bovet: Chimiothérapie des infections streptococciques par les dérivés du p-aminophénylsulfamide. C.R.Soc.Biol. (Paris) 122 (1936) 258-259.

32 J.Tréfouël, J.Tréfoulël, F. Nitti, D. Bovet: Chimiothérapie des infections streptococciques par les dérivés du p-aminophénylsulfamide. Ann. Inst. Pasteur 58 (1937) 30-47.

33 P. Sisley, Ch. Porcher: Du sort des matières colorantes dans l'organisme animal. C.R. Acad.Sci. (Paris) 152 (1911) 1062-1064.

34 L.Colebrook, G.A.H.Buttle, R.A.Q. O'Meara: The mode of action of p-aminobenzenesulphonamide and prontosil in hemolytic streptococcal infections. Lancet (1936II). 1323-1326.

35 K. Kellner: Etude sur l'elimination de la sulphamido-chrysoidine. Thesis, Paris (1936).

36 A.T.Fuller: Is p-aminobenzenesulphonamide the active agent in prontosil therapy? Lancet (1937 I) 194-198.

37 G.Domagk: Weitere Untersuchungen über die chemotherapeutische Wirkung sulfonamidhaltiger Verbindungen bei bakteriellen Infektionen. Klin.Wschr. 16 (1937) 14121418.

38 G.Domagk: $\mathrm{Zu}$ den experimentellen Grundlagen der Chemotherapie der bakteriellen Infektionen mit den Sulfonamiden und ihren Derivaten. D.med.Wschr. 66 (1940) 203-205.

39 L. Colebrook, M.Kenny: Treatment with prontosil of puerperal infections due to hemolytic streptococci. Lancet (1936 II) 1319-1322.

40 L. Colebrook: Prophylactic treatment in obstetrics by means of prontosil and sulphanilamide. Lancet (1937 1 II) 286-288.

41 L. Colebrook, A. W. Purdie: Treatment of 106 cases of puerperal fever by sulphanilamide (streptocide). Lancet (1937 II) 1291-1293.

42 E. K. Marshall jr.: Determination of sulfanilamide in blood and urine. J.biol. Chem. 122 
(1937) 263-273.

43 E. K.Marshall, K.Emerson, W.C.Cutting: Para-aminobenzenesulfonamide. Absorption and excretion: Method of determination in urine and blood. J.Am.Med.Ass. 108 (1937) 953-957.

44 E. K. Marshall jr., K. Emerson jr., W. C. Cutting: The distribution of sulfanilamide in the organism. J.Pharmacol. Exp. Ther. 61 (1937) 196-204.

45 E.K. Marshall jr., K.Emerson jr., W.C.Cutting: The renal excretion of sulfanilamide. J.Pharmacol.Exp. Ther. 61 (1937) 191-195.

46 E.K.Marshall jr., W.C.Cutting, K.Emerson jr.: Acetylation of para-aminobenzenesulfonamide in the animal organism. Science 85 (1937) 202-203.

47 E. K. Marshall, W.C.Cutting, K. Emerson: The toxicity of sulfanilamide. J.Am.Med. Ass. 110 (1938) 252-257.

48 D. Bovet: Recherches expérimentales dans la domaine de la chimiothérapie des infections bactériennes. Schw. med.Wschr. 18 (1937) 288-289.

49 E.M.K.Geiling, P.R.Cannon: Pathologic effects of elixir of sulfanilamide (diethylene glycol) poisoning. J. Am. Med. Ass. 111 (1938) 919-926.

50 T. H. Maren: Relations between structure and biological activity of sulfonamides. Ann. Rev. Pharmacol. Tox. 16 (1976) 309-327.

51 E. Fourneau, J.Tréfouël, J.Tréfouël, F. Nitti, D. Bovet: Action du para-aminophénylsulfamide sur les moisissures. C.R.Soc. Biol. (Paris) 122 (1936) 652-654.

52 M. H. Dawson, G.L. Hobby: Observations on the chemotherapeutic effect of sulfanilamide in experimental hemolytic streptococcal infection. J. Clin. Invest. 17 (1938) 521.

53 D.D. Woods: The relation of p-aminobenzoic acid to the mechanism of the action of sulphonamide. Brit. J.exp. Pathol. 21 (1940) 74-90.

54 D. D. Woods, P. Fildes: The anti-sulphanilamide activity (in vitro) of p-aminobenzoic acid and related compounds. Chem. and Ind. 59 (1940) 133-134.

55 P. Uhlenhut: Demonstration von mit Atoxyl behandelten Dourine-Kaninchen. D. med. Wschr. 33 (1907) 1237.

56 P.Gelmo: Über Sulfamide der p-Aminobenzolsulfonsäure. J.f.prakt.Chemie 77 (1908) $369-382$.

57 C.Bachmann, M.H.Bickel: History of drug metabolism: The first half of the 20th century. Drug Metab.Rev. 16 (1985/6) 185-253.

58 C.D.Klaassen: Heavy metals and heavy-metal antagonists. In: A.G.Gilman, L.S.Goodman, T.W. Rall, F.Murad, (eds.), "The Pharmacological Basis of Therapeutics", Macmillan Publ. Co., New York (1985), 7th ed., 1605-1627.

59 K. Bernhard: Über die Herkunft der Essigsäure bei den Acetylierungen in vivo. Z.physiol. Chemie 267 (1940) 91-98.

60 F.Lipman: Acetylation of sulfanilamide by liver homogenates and extracts. J.Biol. Chem. 160 (1945) 173-190. 


\section{Summary}

Ehrlich's dye theory in chemotherapy culminated in Domagk's discovery of the antibacterial potential of the azo dye, Prontosil, in 1935. Later in the same year Tréfouël, Tréfouël, Nitti, and Bovet at the Institut Pasteur provided evidence that sulfanilamide is the active antibacterial principle and that many of its sulfonamide derivatives are also active. This development which started in Germany and culminated in France soon shifted to Britain and finally to the U.S. where important contributions were made and the therapy with sulfanilamide and a host of sulfonamides was being firmly established.

These events around 1935, particularly the findings of the Institut Pasteur group, had a number of consequences of medico-historical importance. Sulfanilamide marked the end of the dye theory and of the older theory of anti-infective drugs strengthening defense mechanisms of the body. Sulfanilamide, which was not patentable and went immediately into cheap mass production, also prevented Prontosil from becoming a commercial success. The structure-activity relationships worked out by the Institut Pasteur group allowed the development of the numerous sulfonamides, thereby initiating a new era in pharmacotherapy. The isolation and early production of penicillin by Florey and Chain around 1940 was clearly influenced by the success of sulfonamide therapy. The metabolic transformation of inactive Prontosil into active sulfanilamide was a first demonstration of bioactivation which was to bring the theory of detoxication to an end. The elucidation of the mechanism of action of sulfonamides introduced the important concepts of antimetabolites and competitive inhibition into biochemistry and pharmacology. Finally, the deadly drug disaster of 1937, caused by a preparation of sulfanilamide in diethylene glycol, resulted in drug regulatory action providing for safety tests.

\section{Zusammenfassung}

Ehrlichs Farbstofftheorie der Chemotherapie erreichte ihren Höhepunkt 1935 mit der Entdeckung der antibakteriellen Wirkung des Azofarbstoffs Prontosil durch Domagk. Später im selben Jahr konnten Tréfouël, Tréfouël, Nitti und Bovet im Institut Pasteur zeigen, daß diese antibakterielle Wirkung auf der Bildung von Sulfanilamid beruht und daß zahlreiche seiner Sulfonamid-Derivate ebenfalls aktiv sind. Diese Entwicklung, welche in Deutschland begann und in Frankreich ihren Höhepunkt erreichte, verlagerte sich bald nach Großbritannien und schließlich in die USA, wo wichtige Beiträge geleistet wurden und die Therapie mit Sulfanilamid und zahlreichen Sulfonamiden auf eine feste Basis gestellt wurden.

Diese Ereignisse um 1935, vor allem die Entdeckungen der Gruppe am Institut Pasteur, hatten eine Anzahl von Konsequenzen von medizingeschichtlicher Bedeutung. Mit Sulfanilamid kam die Farbstofftheorie an ihr Ende, gleichzeitig aber auch die ältere Theorie, nach welcher Chemotherapeutika die Abwehrmechanismen des Körpers stärken. Sulfanilamid, welches nicht patentierbar war und sofort in billige Massenproduktion ging, verhinderte einen kommerziellen Erfolg von Prontosil. Die von der Institut-Pasteur-Gruppe ausgearbeiteten Struktur-Aktivitäts-Beziehungen führten zu Entwicklung zahlreicher Sulfonamide und damit zu einer neuen Ära der Pharmakotherapie. Diese hat zweifellos auch die Isolierung und frühe Herstellung von Penicillin durch Florey und Chain um 1940 beeinflußt. Die metaboli- 
sche Umwandlung von inaktivem Prontosil zu aktivem Sulfanilamid war das erste Beispiel einer Bioaktivierung, welche in den folgenden Jahren die Theorie der Detoxikation an ihr Ende brachte. Die Aufklärung des Wirkungsmechanismus von Sulfonamiden führte zu den für die Biochemie und die Pharmakologie so wichtigen Konzepten der Antimetabolite und der kompetitiven Hemmung. Schließlich führte die Arzneimittelkatastrophe von 1937, bedingt durch in Diäthylenglykol gelöstes Sulfanilamid, zu gesetzgeberischen Schritten, durch welche die Sicherheit von neuen Arzneimitteln durch toxikologische Prüfung gewährleistet werden sollte.

Prof. M. H. Bickel

Department of Pharmacology

Friedbühlstrasse 49

CH-3010 Bern, Switzerland 